\title{
Recent faulting along Gorontalo fault based on seismicity data analysis and lineament mapping
}

\author{
Hasan Arif Efendi ${ }^{1,2 *}$, Gayatri Indah Marliyani ${ }^{2}$, and Subagyo Pramumijoyo ${ }^{2}$ \\ ${ }^{1}$ Badan Meteorologi Klimatologi dan Geofisika (BMKG), Stasiun Geofisika Gorontalo, Talumelito Gorontalo, Indonesia \\ ${ }^{2}$ Universitas Gadjah Mada, Department of Geological Engineering, Jl. Grafika No. 2 Yogyakarta, Indonesia
}

\begin{abstract}
We focused our study to characterize the geometry and activity of Gorontalo fault. We analysed reviewed the ISC seismic catalogue and the BMKG relocated earthquake events available for the time period of 1960 to 2021, located along the expected location of this fault. In addition, we analysed continuous record from local seismic observatory available for the same period. Further, we mapped the lineaments using 8.3$m$ resolution DEMNAS data. Tens on shallow earthquakes occurred in the vicinity of this fault with a range magnitude of M 2 to 3. Our lineament analysis however does not reveal distinctive pattern that may indicate the fault manifestation at the surface. The NW-SE trending lineaments are coincidence with the mapped trace of Gorontalo Fault. The weak surface manifestation of the fault scarp may be related to the tropical climatic condition of the area which may obliterate the faulting topography. However, we observed alignment of the seismicity distribution with the mapped NW-SE lineament, indicating that the lineament is likely representing active fault and these earthquakes are associated with faulting along this fault. Our study provide indication that the Gorontalo Fault is active and further study is necessary to investigate subsurface geometry and mitigate its seismic hazards.
\end{abstract}

\section{Introduction}

\subsection{Background}

Gorontalo lies on the northern arm of Celebes Island known as Minahasa Peninsula. This region is located in an active tectonic region, as a result of convergence of Eurasian, Pacific and Australian plates. The triple plate junction in this area is characterized by the subduction of Celebes Sea plate in the north beneath the Minahasa Peninsula underlying Moluccas double subduction to the east [1] producing high seismicity. Based on historical data from the Indonesian Agency for Meteorology, Climatology, and Geophysics (BMKG), destructive earthquakes with magnitude higher than $\mathrm{M}$ 7 occurred in Gorontalo in 1990, 1991, 1997 and 2008 and was reported to occur along the Celebes subduction. There were also destructive events felt throughout Gorontalo area in 1939 and 1941, however the hypocentre location of these earthquakes was unknown and it is unclear whether they were originated from an inland fault or from the subduction.

There are several known active faults near the city of Gorontalo (716,603 inhabitants), exposing the community to earthquake hazards. One of the major fault is the NW-SE trending Gorontalo Fault but this fault is not well studied. Difficulties of characterizing the Gorontalo Fault is possibly because of the lack of detailed seismic monitoring data and diffused geomorphic expression of the fault. Nowadays, establishment of new seismic network and the availability of the $8.3-\mathrm{m}$ resolution DEMNAS provide opportunity to better asses the fault zone. We focused our study to characterize the geometry and activity of this fault using these new available data. The aim of this study is to identify the correlation between lineaments and seismicity distribution. Results from our study will contribute toward better understanding of the Gorontalo fault zone and supporting the development of seismic hazard maps in the city of Gorontalo.

The purpose of this study is to introduce a new perspectives of Gorontalo Fault. The previous study data is not adequate enough to provide evidence of active deformation. A fault is categorized as active if it has moved within the past 10,000 years (Holocene) [1]. So, earthquake, lineament trace of remote sensing image, and visual deformation evidence are proof of an active fault as recent deformation.

\subsection{Regional Geology of Gorontalo Fault}

The Gorontalo Fault has been identified as a transcurrent fault, oriented to the NW-SE [2] and consist of several smaller fault segments [3-5]. The fault accommodates the different velocity between the east and west block of Minahasa Peninsula which is estimated to be around 11 $\mathrm{mm} /$ year based on geodetic modelling [6]. However, there were no major earthquakes recorded along

\footnotetext{
* Corresponding author: hasan.a.e@mail.ugm.ac.id
} 
Gorontalo Fault [7] in historical record as well as during a temporary seismic network campaign in 1990 [6].

The activity of this fault is overlooked because of the absent of major earthquakes in historic years and the diffused expression of the fault in the topography $[8,9]$. The Fault consists of several branching segments and categorized as slow-slip faults [10]. There are no strong agreement about the fault is active or not, although recent movement of this fault was identified through GPS observation[11,12] and through the occurrence of small-medium earthquakes along this fault.

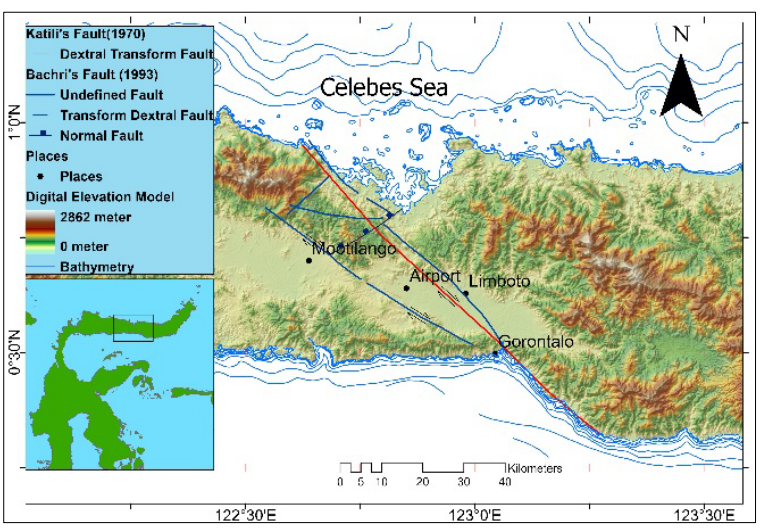

Fig. 1. Map showing study area of Gorontalo Fault where orange line represents Katili's active fault (1970) then blue line is geometry of Gorontalo Fault Zone were mapped by Bachri (1993).

\section{Data and method}

To characterize the geometry and activity of this fault we analyse the seismicity and topography along the expected trace of the fault zone. We retrieved 479 crustal shallow earthquake data (depth $\geq 30 \mathrm{~km}$ ) from $\mathrm{BMKG}$ and International Seismological Centre (ISC) from 1960 to 2021. Based on the slab geometry inferred from ISC-EHB Bulletin[6] and SLAB2 model [13], the hypocentre below $30 \mathrm{~km}$ can be considered as intraplate events, and is likely caused by inland fault activity. The BMKG data include arrival time series recorded by the BMKG national network and data from the local observatory (BMKG Gorontalo geophysical station). Both of the central and local observatory network continuously monitor the seismicity, but the local observatory network, which was established in 2017 , provide additional advantage through its capabilities to identify small magnitude earthquakes. We relocated the recorded events using Seiscomp3 software[14,15] to obtain better accuracy of the epicentre location. We also recalculate the hypocentre using HYP module of the SEISAN program[16] using CRUST 1.0 velocity model[17].

The fault expression on the Earth's surface can be identified by mapping linear feature in the topography. However, lineament may controlled by many different processes, including geological structure, lithological contacts, or human modification, therefore should be interpreted cautiously. We eliminate some of the lineaments that are not related to geological structure and focusing our observation to the suspected tectonic- related lineaments. The fault-related lineament usually can be identified through series of geomorphic offsets (river, hill, terraces, etc). The lineaments was manually delineated, some of the distinctive characteristics including: 1) the occurrence of fault scarp; expressed as prominent linear feature on topography, for example fluvial system creating linear valleys, series of aligned ridge and saddles 2) linear mountain fronts and linear coast 3) series of systematic drainage offset.

Table 1. Local crustal velocity model around Gorontalo Fault at $0.5 \mathrm{~N}-122.5 \mathrm{E}$ generated from CRUST 1.0[17].

\begin{tabular}{lccc}
\hline \multicolumn{1}{c}{ Type } & $\begin{array}{c}\mathrm{Vp} \\
(\mathrm{km} / \mathrm{s})\end{array}$ & $\begin{array}{c}\mathrm{Vp} \\
(\mathrm{km} / \mathrm{s})\end{array}$ & $\begin{array}{c}\text { Depth } \\
(\mathrm{km})\end{array}$ \\
\hline $\begin{array}{l}\text { Upper } \\
\text { Sedimentary }\end{array}$ & 1.75 & 0.34 & 0.48 \\
Upper Crust & 5.8 & 3.4 & 1.18 \\
Middle Crust & 6.3 & 3.62 & 10.98 \\
Lower Crust & 6.9 & 3.94 & 20.49 \\
& & & \\
Mantle & 7.84 & 4.37 & 30 \\
\hline
\end{tabular}

For the lineament analysis, we use an $8.3 \mathrm{~m}$ resolutions digital elevation model (DEM) from DEMNAS (https://tanahair.indonesia.go.id/demnas/). We processed the DEM, creating various relief map using relief visualization (RVT) toolbox [18]. For the data integration and analysis, we use ArcGIS software. For the lineament orientation analysis, we only consider the long and firm lineaments. We conducted limited field check along the suspected tectonically-controlled lineaments to confirm their tectonic origin and to obtain any fault geometry indication.

We then overlay the suspected active fault map with seismicity distribution to see if the seismicity coincide with the lineaments and may represent recent faulting along the fault.

\section{Result}

We relocated 219 earthquakes from the BMKG data repository (2010 to 2021) and 111 events from the BMKG local observatory (2016-2017). In addition, we compiled it with 149 events from the ISC catalogue (1960 to 2009). We disregarded events recorded by only one station, for their lacking of arrival time data necessary for the relocation processes. We were able to reduce the average mean square error of the original catalogue from 0.6608 to 0.6286 and provide a better accuracy of their location. Some of the hypocentres were shifting to shallower depth. However, the distribution of the epicentre is scattered. 


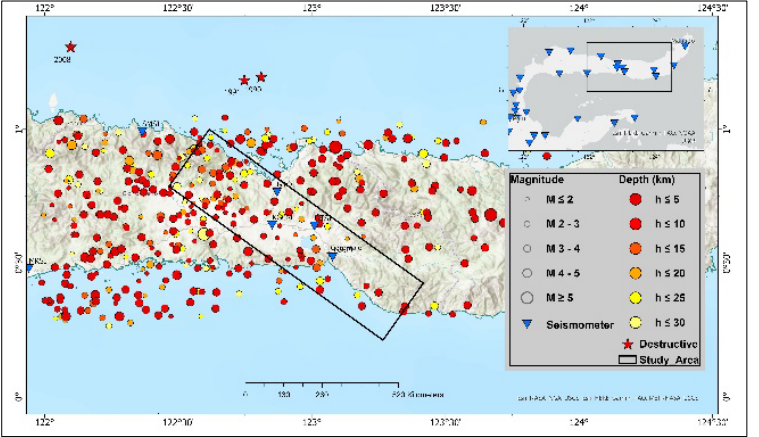

Fig. 2. Relocated seismicity of the BMKG repository and local BMKG station calculated using HYP module of SEISAN. Red stars indicate epicentre of destructive earthquake occurred along the North Celebes subduction (listed on ISC-EHB catalogue). Black box delineate our study area.

The distribution of lineament from our mapping indicate the lineaments are concentrated along the high relief topography oriented to the NW-SE, inferred as the Gorontalo fault zone. However, we were not able to locate the surface trace of the fault solely from the smallscale lineaments (Fig. 3). We also identify series of NESW lineaments that may represent another active fault zone.

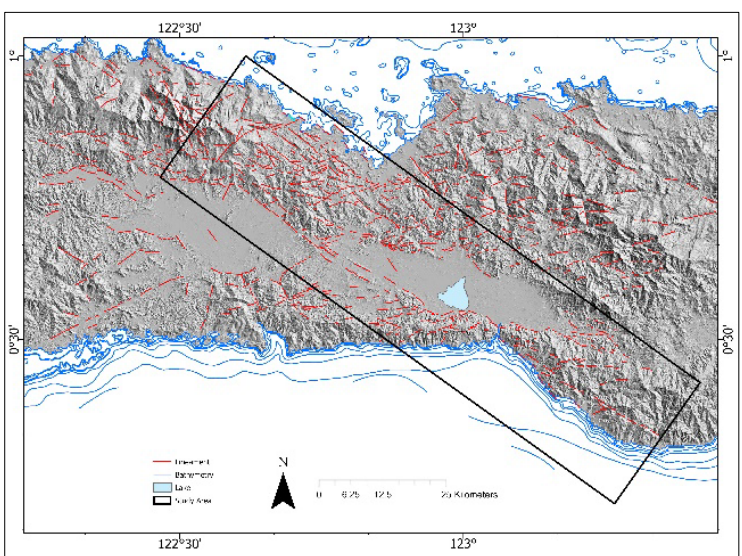

Fig. 3. Lineament map of the study area based on shaded relief DEMNAS data (tanahair.indonesia.go.id/demnas/). Red lines show the delineated lineaments that are likely tectonicorigin. Black box delineate our study area.

Following the lineament analysis, we conducted field checking along the suspected tectonic-origin lineaments. We documented recent deformation evidence of minor faults along the NE-SW trending lineaments in several area (Fig. 4). We also found two series of NW-SE trending triangular facets in Mootilango area (Fig.4). Near the Limboto Lake, we identify E-W oriented normal faults on the Quaternary limestone and loose Quaternary sediments. We also found several secondary faulting displacing several older sedimentary units with varying orientations.

\section{Discussion}

We interpreted the NW-SE trending major lineament representing the active trace of the Gorontalo fault zone represented by tens shallow earthquake occurred along our mapped Gorontalo fault zone. The clustered nature of the seismicity in this area may possibly related to the nature of sparse regional seismic network that may not able to provide accurate measurement of local events. The slab depth beneath our study area is at depth of 50 $\mathrm{km}$ [13], so the events that were originated above $30 \mathrm{~km}$ are likely sourced along active inland faults rather than subduction-related events. Based on this observation, we use $30 \mathrm{~km}$ as the maximum seismic depth for crustal events and use the distribution of events to characterize inland crustal faults. The spatial distribution of the earthquake indicate that the western side of Gorontalo is more active seismically in compare to its eastern side (Figure 3). The linear distribution of seismicity along the fault zone provide good indication that this fault is active.

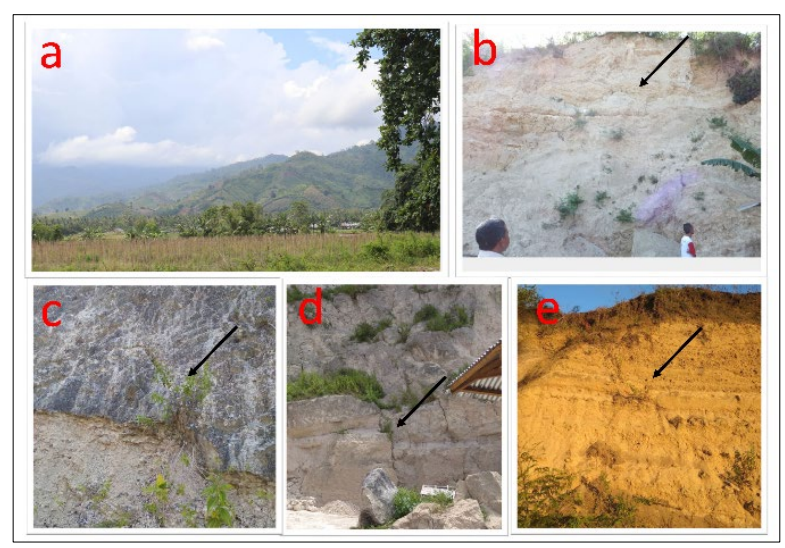

Fig. 4. Photographs show indications of faulting along Gorontalo Fault. (a) linear topographic break showing triangular facets oriented to the NW at Mootilango area, camera face to the N. (b), (c) \& (d) photographs of outcrops show faults dissecting Quaternary limestone at Gorontalo Bay and Limboto. (e) minor normal fault displacing loose Quaternary sediment near Limboto Lake.

The large scale Gorontalo Fault was originally identified based on the offset of the coastline toward its NW and SE ends [1]. However, the topographic expression of this suspected fault orientation is difficult to be observed with the mainland (Figure 4). The limitation of the surface manifestation of the fault scarp may be related to the tropical climatic condition of the area which may obliterate the faulting topography. The only observable geomorphic feature that may indicate this fault is a shutter ridge near the Gorontalo airport and few scarps and triangular facets observed in the Mootilango area (Figure 4). We estimate the geometry of the fault based on their field expression as well as from the depth distribution of shallow seismicity along the fault zone (Fig.5). Although most of the profile show diffused distribution, the seismic depth profile across one prominent lineament show indication of high angle NE-dipping fault (profile C-C', Figure 5). With the limitation of hypocentres distribution and the surface manifestation of the fault, characterization of the fault through subsurface investigation can be implemented for future study, for example using geophysical methods, to estimate the fault geometry. 


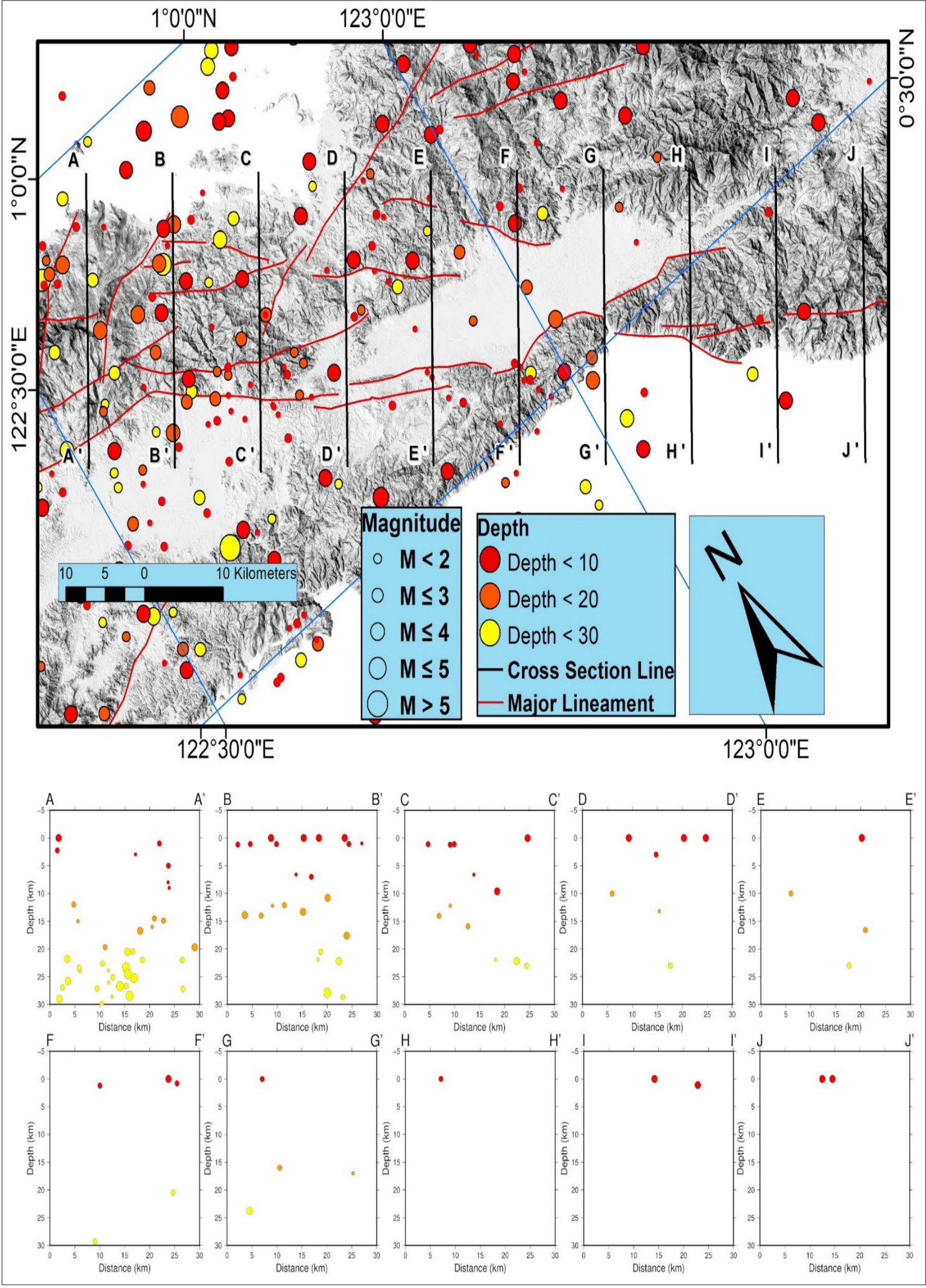

Fig. 5. Depth Distribution and cross section of shallow seismicity in the study area. 


\section{Conclusion}

We presented the lineament and seismicity analysis of the Gorontalo fault zone. The alignment of the seismicity distribution with the mapped NW-SE lineament, indicating that the lineament is likely representing geometry of active fault and these earthquakes are associated with faulting along this fault. Several indications of recent faulting are also found in the field as the faults dissecting Quaternary age units. The activity of the fault also confirmed through the occurrence of shallow earthquakes that are clustered along the mapped lineament. All of these suggesting that the Gorontalo fault is active and is capable to produce earthquakes in the future. Further investigation to characterize the fault in detail is necessary to mitigate hazards associated with this fault. Future investigation of the subsurface data is necessary to obtain the fault geometry at depth and further asses their seismic potentials.

We thank BMKG for earthquake catalogue and BIG for DEMNAS data. This study was supported by Research Grant of Lembaga Pengelola Dana Pendidikan (LPDP) 2018.

\section{References}

1. E. A. Keller and N. Pinter, Active Tectonics, 2nd Edition (Prentice Hall, New Jersey, 2002)

2. J. A. Katili, Geol. Rundschau 59, 581 (1970)

3. S. Bachri, Sukido, and N. Ratman, Peta Geologi Lembar Tilamuta, Sulawesi, Skala 1:250.000 (Bandung, 1993)

4. T. Apandi and S. Bachri, Peta Geologi Lembar Kotamoagu, Sulawesi, Skala 1:250.000 (Bandung, 1997)

5. J. Weston, E. R. Engdahl, J. Harris, D. Di Giacomo, and D. A. Storchak, Geophys. J. Int. 214, 474 (2018)

6. S. S. Bawono, E. Partoyo, S. Wiryosujono, R. L. Situmorang, and R. J. . Supandjono, Peta Geologi Lembar Limboto, Sulawesi, Skala 1:100.000 (Bandung, 1999)

7. P. C. Thenhaus, S. L. Hanson, I. Effendi, E. K. Kertapati, and S. T. Algermissen, Earthq. Spectra 9, 97 (1993)

8. J. Surmont, C. Laj, C. Kissel, C. Rangin, H. Bellon, and B. Priadi, Earth Planet. Sci. Lett. 121, 629 (1994)

9. P. Molnar and K. E. Dayem, Geosphere 6, 444 (2010)

10. I. M. Watkinson and R. Hall, Geol. Soc. Spec. Publ. 441, 71 (2017)

11. C. Rangin, X. Le Pichon, S. Mazzotti, M. Pubellier, N. Chamot-Rooke, M. Aurelio, A. Walpersdorf, and R. Quebral, Geophys. J. Int. 139, 296 (1999)

12. A. Socquet, W. Simons, C. Vigny, R. McCaffrey, C. Subarya, D. Sarsito, B. Ambrosius, and W. Spakman, J. Geophys. Res. Solid Earth 111, (2006)
13. G. P. Hayes, G. L. Moore, D. E. Portner, M. Hearne, H. Flamme, M. Furtney, and G. M. Smoczyk, Science (80). 362, 58 (2018)

14. B. Weber, J. Becker, W. Hanka, A. Heinloo, M. Hoffman, T. Kraft, D. Pahlke, J. Reinhardt, J. Saul, and H. Thoms, in EGU Gen. Assem. Conf. Abstr. (2007)

15. GFZ German Research Centre for Geosciences and gempa GmbH, (2008)

16. J. Havskov, P. H. Voss, and L. Ottemöller, Seismol. Res. Lett. 91, 1846 (2020)

17. G. Laske, G. Masters, Z. Ma, and M. Pasyanos, EGU Gen. Assem. 2013 15, 2658 (2013)

18. Ž. Kokalj and M. Somrak, Remote Sens. 11, (2019) 